\title{
MENGKAJI KRISIS EKONOMI GLOBAL MENURUT PERSPEKTIF ISLAM
}

\author{
Wening Purbatin Palupi Soenjoto \\ Sekolah Tinggi Agama Islam At-Tahdzib Jombang, Indonesia \\ E-mail: kekuatandoacinta@ymail.com
}

\begin{abstract}
s
The global economic crisis is an event in which all economic sectors world market collapse or degresi and affect other sectors around the world. The global economic crisis originated from the United States (US), and then spread to almost all countries of the world. In the view of Islam, in fact the economic crisis that the world can not be separated from economic practice at practices or economic activities done contrary to Islamic law. In Islam there are three ways to minimize the economic crisis, namely: Equal distribution of wealth to charity, developing banking with Sharia'ah system, and a system using the currency dinâr and dirhâm. If three ways really implemented in one country, will likely impact the country can improve the global economic crisis in the country.
\end{abstract}

Keywords: Global Economic Crisis, Islamic, Poverty, Zakat, Islamic System, Dinâr and Dirhâm. 


\section{Pendahuluan}

Amerika Serikat, merupakan negara maju yang dikenal sebagai pusat perekonomian di dunia. Amerika Serikat pun mencatat sejarah kelam dalam perekonomian karena mengalami krisis ekonomi pada tahun 2008 yang diawali dengan kebangkrutan Leman Brothers yang merupakan salah satu perusahaan investasi atau bank keuangan senior dan terbesar ke empat di Amerika Serikat. Siapa yang menyangka suatu negara yang merupakan tembok kapitalis dunia akan runtuh dan bangkrut seperti itu. Dan celakanya apa yang terjadi di Amerika Serikat dan dampaknya pun menyebar keseluruh dunia, termasuk juga Indonesia

Sebenarnya terjadinya krisis ekonomi tidak bisa lepas dari praktikpraktik atau aktivitas ekonomi yang bertentangan dengan nilai-nilai syariat Islam. Seperti adanya riba, monopoli, korupsi, dan tindakantindakan lain yang bertentangan dengan syariat Islam. Bila pelaku ekonomi terbiasa dengan tindakan-tindakan yang bertentangan dengan syriat Islam, krisis ekonomi mungkin saja terjadi sebagai malapetaka dan teguran karena kita tidak memperhatikan dan tidak mematuhi syariat. Dan justru malah menjadikannya sebagai kebiasaan dan hal yang biasa dimasyarakat.

\section{Pembahasan}

Krisis ekonomi global adalah peristiwa di mana seluruh sektor ekonomi pasar dunia mengalami keruntuhan atau degresi dan mempengaruhi sektor lainnya di seluruh dunia. Krisis ekonomi global terjadi karena permasalahan ekonomi pasar dunia yang tidak dapat dielakkan sebab kebangkrutan maupun adanya situasi ekonomi yang berantakan. Sektor yang terkena imbas krisis ekonomi global adalah seluruh sektor bidang kehidupan.

Krisis ekonomi global berawal dari Amerika Serikat (AS), kemudian menjalar ke hampir seluruh negara-negara dunia. Bukan hanya negaranegara maju yang terkena imbas krisis, namun juga negara-negara berkembang. Krisis ekonomi secara nyata mengarah ke resesi. Pada mulanya, krisis ini dipicu oleh kemacetan kredit perumahan di AS, karena para pemilik rumah tak mampu membayar cicilan kredit. Itulah sebabnya krisis ini dinamai subprime mortgage. Kemacetan itu merembet ke manamana, bukan hanya ke perusahaan yang terlibat dalam pemberian kredit, namun juga ke perusahaan penjamin kredit, dan asuransi kredit perusahaan. Dalam perkembangannya, krisis ini juga berimbas pada sektor riil. Keterpurukan sektor perbankan di AS yang ditandai dengan kekurangan modal mengakibatkan banyak lembaga keuangan bangkrut. 
Bukan saja lembaga keuangan di AS, namun juga bank-bank internasional di Eropa dan di Asia. Akibatnya, kemampuan perbankan internasioal dalam mengucurkan dananya kepada sektor rill semakin menurun.

Negara-negara Asia tenggara akan menghadapi masa sulit dengan perlambatan ekonomi di AS dan juga mendapat persaingan dari Cina. Negara-negara Asia akan berkompetisi untuk memperebutkan hal yang semakin kecil apabila impor AS mengecil. Dunaway juga memperkirakan, kemungkinan Cina akan menurunkan harga untuk lebih meningkatkan daya saingnya. Apabila kondisi ini benar-benar terjadi, maka hal ini akan menambah tekanan terhadap negara-negara Asia Tenggara.

Bagi Indonesia, dampak negatif dari krisis finansial global yang berlarut-larut sudah mulai terasa. Dampak ini sudah mulai terlihat dari pembiayaan kegiatan investasi yang semakin menciut, dan penyerapan tenaga kerja yang melambat. Hal ini menyebabkan daya beli masyarakat turun, dan akhirnya pertumbuhan ekonomi pun menurun. Dalam kondisi seperti ini para pengusaha akan memikirkan langkah efisien untuk mengurangi dampak kerugian suatu perusahaan. Dan yang akan menjadi korban pun biasanya para karyawan atau pekerja diperusahaanperusahaan tersebut, karena mereka akan mengalami pemutusan hubungan kerja (PHK). Hal ini merupakan konsekwensi dari daya saing produk Indonesia yang terus berkurang, sementara biaya produksi semakin meningkat. Dengan adalah PHK bagi para karyawan atau pekerja di perusahaan-perusahaan tersebut akan menimbulkan masalah baru dikemudian harinya jika para karyawan tersebut tidak segera mendapatkan pekerjaan yang baru. Salah satunya adalah akan menimbulkan masalah kemiskinan dan penganggguran bagi mereka yang tidak mendapatkan pekerjaan.

Di Indonesia masalah kemiskinan terus menjadi perhatian pemerintah. Bukan saja belakangan ini, namun sejak negara ini berdiri. Hal ini sebagaimana termuat dalam alinea keempat Undang-Undang Dasar 1945. Yang berisi program-program upaya pengentasan kemiskinan. Itu karena pembangunan yang dilakukan selama ini juga selalu sangat menekankan upaya pengentasan kemiskinan. Itu karena pembangunan yang dilakukan pada dasarnya bertujuan untuk meningkatkan kesejahteraan masyarakat. Meski demikian, masalah 
kemiskinan sampai saat ini terus-menerus menjadi masalah yang berkepanjangan. ${ }^{1}$

Berbagai program pengentasan kemiskinan yang dilaksanakan pemerintah selama ini tampaknya belum berjalan efektif. Setidaknya hal ini ditunjukkan dengan perkembangan jumlah penduduk miskin. Pada akhir tahun 2000 jumlah penduduk miskin mencapai 37,3 juta jiwa atau $19,0 \%$ dari jumlah penduduk. Jumlah itu menurun menjadi 35,1 juta jiwa atau sekitar 16\% dari jumlah penduduk pada tahun 2005. Namun pada tahun 2006, jumlahnya meningkat kembli menjadi 39,05 juta atau sekitar $17,8 \%$ dari seluruh jumlah penduduk Indonesia. Dalam tahun yang sama, diperkirakan masih terdapat 7 juta keluarga atau sekitar 30 juta penduduk dalam kategori nyaris miskin dan sangat rentan terhadap goncangan keadaan.

Sejak dekade 1990-an pemerintah mengeluarkan berbagai program kemiskinan, seperti Program Pengembangan Wilayah terpadu, Jaring Pengaman Sosial, dan masih ada bentuk program pengentasan kemiskinan lainnya. Ditilik dari isi program tersebut sebenarnya cukup bagus. Kelebihannya adalah bahwa program ini lebih bersifat memberi kail kepada masyarakat miskin, dan bukan memberi ikan. Apabila pemerintah berpegang teguh ada aturan main pelaksanaan program tersebut, dapat dipastikan bahwa kemiskinan dapat berkurang secara signifikan. Namun sayang, dalam praktiknya, banyak sekali penyelewengan yang dilakukan oleh pelaksana program. Berdasarkan hasil pengamatan, modus penyelewengan natara lain: Mark up dana; komponen honor dalam pendanaan program pengentasan kemiskinan ini lebih dominan daripada dana yang dikucurkan ke masyarakat; kesalahan pemilihan sasaran penerima bantuan. Semua penyelewengan terjadi karena tidak ada akses dari pihak luar untuk mengawasi pelaksanaan program.

\section{Faktor Penyebab Kegagalan Program.}

Kegagalan pemerintah dalam menurunkan angka kemiskinan bukan semata-mata disebabkan oleh metode perhitungan garis kemiskinan dan program bantuan yang akan diberikan kepada masyarakat miskin. Ada beberapa hal yang menyebabkan program pemerintah gagal, yaitu:

Pertama, Bentuk program pengentasan kemiskinan seperti bantuan Tunai Langsung (BTL) dan Bantuan Tunai Bersyarat (BTB) tidak akan

\footnotetext{
1 Makmun Syadullah, Krisis Ekonomi Global \& Dampak Fiskal (Yogyakarta: Tiara Wacana, 2010), 42.
} 
mampu menjawab permasalahan. Program-program seperti ini hanya sebatas mampu meringankan pengeluaran konsumsi masyarakat miskin sesaat. Apabila program seperti ini diberhentikan, mereka kembali menjadi miskin. Di samping itu program seperti ini juga tidak mendidik, bahkan sebaliknya dapat berakibat semakin menyuburkan budaya mintaminta.

Kedua, Kurangnya pengawasan terhadap program-program pengentasan kemiskinan. Selama ini pengawasan hanya dilakukan sebatas penggunaan anggaran, sehingga apabila terjadi pelanggaran di lapangan tidak bisa terdeteksi. Pengawasan itu pun dilakukan oleh aparat pemerintahan sendiri, tanpa melibatkan pihak luar.

Ketiga, Program-program penanggulangan kemiskinan selama ini cenderung berfokus pada upaya penyaluran bantuan sosial untuk orang miskin. Hal itu, antara lain berupa pemberian beras untuk rakyat miskin (Raskin) dan program Jaring Pengaman Sosial (JPS) untuk orang miskin. Upaya seperti ini tidak akan sulit menyelesaikan persoalan kemiskinan yang ada karena sifat bantuan ini tidaklah untuk pemberdayaan, tetapi justru dapat menimbulkan ketergantungan.

Keempat, Kurangnya pemahaman berbagai pihak tentang penyebab kemiskinan itu sendiri, sehingga program-program pembangunan yang ada tidak didasarkan pada isu-isu kemiskinan yang menyebabkan berbeda-beda secara lokal.

Berdasarkan kondisi dan rencana program pemerintah dalam menurunkan angka kemiskinan, disamping difokuskan pada pemberian beras untuk rakyat miskin (Raskin) dan program Jaring Pengaman Sosial (JPS), sebaiknya juga memperhitungkan dimensi lainnya di kehidupan manusia. Karena kemiskinan tidak hanya berhubungan dengan kemampuan memenuhi kebutuan material saja. Kemiskinan hanya dapat ditaggulangi apabila dimensi-dimensi lain juga diperhatikan. Dimensidimensi lain yang dimaksud antara lain:

a. Ketersediaan bahan kebutuhan dasar.

b. Sarana dan prasarana.

c. Kebijakan pembangunan perkotaan.

d. Produktifitas dan kemampuan mengelola sumber daya alam dan lingkungannya.

e. Tata pemerintahan yang bersih dan baik.

f. Pengelolaan sumber daya alam yang tidak berlebihan dan berwawasan lingkungan.

Program-program bantuan yang berorientasi pada kedermawanan pemerintah justru dapat memperburuk moral dan perilaku masyarakat 
miskin. Program bantuan untuk orang miskin seharusnya lebih difokuskan untuk menumbuhkan budaya ekonomi produktif dan kemampuan membebaskan ketergantungan penduduk yang bersifat permanen. Di lain pihak, program-program bantuan sosial juga dapat menimbulkan korupsi dalam penyalurannya. Akan lebih baik apabila dana-dana bantuan dari pemerintah langsung digunakan untuk peningkatan sumberdaya manusia, seperti dibebaskannya biaya untuk sekolah, seperti sekolah dasar (SD) dan sekolah menengah pertama (SMP), serta dibebaskannya biaya-biaya pengobatan di pusat kesehatan masyarakat (Puskesmas). ${ }^{2}$

Namun pada kenyataannya meskipun ada bantuan untuk meringankan biaya pendidikan untuk sekolah dasar (SD), dan sekolah menengah pertama (SMP) banyak yang penyalurannya tidak tepat sasaran. Dan bahkan ada anak yang kurang mampu atau miskin malah tidak mendapatkan bantuan keringanan tersebut. Untuk biaya pengobatan di Puskesmas atau pun rumah sakit bagi masyarakat miskin juga telah ada. Namun selain permasalahan tidak tepat sasaran, juga pelayanan bagi masyarakat yang menggunakan bantuan keringanan ini akan berbeda dengan pelayanan yang murni membayar sendiri. Dalam pemberian obat pun juga dibedakan. Tak jarang rumah sakit dan puskesmas memberikan pelayanan yang lambat bagi masyarakat yang menggunakan bantuan keringanan dari pemerintah tersebut. Padahal seharusnya tidak ada pembedaan bagi masyarakat yang menggunakan keringanan dari pemerintah dengan yang murni menggunakan biaya sendiri. Akibatnya banyak masyarakat miskin yang tidak tertolong atau tidak bisa berobat karena mereka mengandalkan bantuan dari pemerintah, sedangkan pihak kesehatan tidak begitu mementingkan mereka yang tidak memiliki cukup uang untuk berobat dan hanya mengandalkan jaminan dari pemerintah.

Selain hal-hal diatas, di Indonesia imbas krisis ekonomi dalam bidang lainnya juga mulai terasa menjelang akhir tahun 2008. Hal itu tercermin dari pelambatan ekonomi secara signifikan, terutama karena kinerja ekspor anjlok. Di sisi eksternal, defisit neraca pembayaran Indonesia meningkat cukup signifikan sehingga nilai tukar rupiah melemah. Di pasar keuangan, selisih resiko surat-surat berharga Indonesia meningkat cukup signifikan sehingga mendorong arus modal keluar dari investasi asing di bursa saham, Surat Utang Negara (SUN), dan sertifikat Bank Indonesia (SBI). Secara relatif, posisi Indonesia sendiri secara umum bukanlah yang terburuk diantara negara-negara lain.

\footnotetext{
2 Ibid, 43.
} 


\section{Cara Mengatasi Krisis Ekonomi Global Oleh Pemerintah Indonesia.}

Presiden menegaskan Lima langkah yang harus ditempuh semua pihak untuk menghadapi krisis keuangan yang terjadi di Amerika Serikat (AS), sehingga tidak berdampak buruk terhadap pembangunan nasional. Cara-cara tersebut yaitu:

Pertama, Presiden mengajak semua pihak dalam menghadapi krisis ekonomi global harus terus memupuk rasa optimisme dan saling bekerjasama sehingga bisa tetap menjaga kepercayaan masyarakat.

Kedua, Pertumbuhan perekonomian harus tetap dipertahankan dengan cara terus mencari peluang ekspor dan investasi serta mengembangkan perekonomian domestik. Adapun cara pengembangan perekonomian domestik diantaranya yaitu:

a. Dengan cara mengembangkan tempat-tempat wisata yang ada di Indonesia sendiri. Karena Indonesia merupakan negara dengan banyak tempat-tempat wisata yang ada didalamnya. Jika tempattempat wisata diseluruh Indonesia dikelola dengan baik, tentu bisa meningkatkan pendapatan negara.

b. Meningkatkan kualitas barang-barang yang diproduksi oleh Indonesia. Sehingga peluang untuk ekspor pun akan semakin meningkat.

c. Meningkatkan kualitas budaya-budaya yang ada di Indonesia. Dengan meningkatnya kualitas budaya yang ada di Indonesia akan bisa menarik perhatian para turis untuk datang ke Indonesia.

d. Optimalisasi APBN untuk terus memacu pertumbuhan dengan tetap memperhatikan beberapa hal seperti infrastruktur, alokasi penanganan kemiskinan, ketersediaan listrik serta pangan dan BBM. Maka dari itu perlu adanya efisiensi penggunaan anggaran APBN maupun APBD khususnya untuk kegiatan konsumsi.

e. Ajakan pada kalangan dunia usaha untuk tetap mendorong sektor riil dapat bergerak.

f. Semua pihak harus lebih kreatif menangkap peluang dimasa krisis. Antar lain dengan mengembangkan pasar dinegara-negara tetangga kawasan Asia yang tidak secara langsung terkena pengaruh krisis keuangan dari Amerika Serikat (AS).

g. Meningkatkan kembali penggunaan produk dalam negeri sehingga pasar domestik akan bertambah kuat. Dalam hal ini perlu menumbuhkan kesadaran mayarakat agar lebih menyukai dan menggunakan produk sendiri daripada produk luar negeri. Karena pada kenyataannya dengan berbagai alasan lebih banyak masyarakat di 
Indonesia yang lebih suka menggunakan produk luar negeri daripada produk sendiri. Diantara alasan-alasan tersebut adalah:

1. Barang luar negeri lebih murah jika dibandingkan dengan produk dalam negeri.

2. Kualitas barang luar negeri lebih baik dibandingkan dengan produk dalam negeri.

3. Lebih mudah mencari produk luar negeri dibandingkan dengan produk dalam negeri.

Padahal banyak produk-produk dalam negeri yang kualitasnya lebih baik daripada produk luar negeri. Dan mungkin karena kualitasnya yang bagus maka harganya pun akan lebih mahal daripada produk-produk yang berasal dari luar negeri. Lebih miris lagi jika melihat kenyataan produk-produk dalam negeri yang dianggap mahal oleh masyarakat dalam negeri tapi justru menjadi incaran dari para konsumen luar negeri. Karena tak sedikit pula produk-produk dalam negeri yang tembus pasaran sampai ke luar negeri. Maka kesadaran masyarakat adalah salah satu kunci untuk meningkatkan pendapatan domestik.

Ketiga, Perlunya penguatan kerjasama lintas sektor antara pemerintah, bank Indonesia, dunia perbankan serta sektor swasta.

Keempat, Semua kalangan diharapkan untuk menghindari sikap mementingkan egonya dan memandang remeh masalah yang dihadapi.

Kelima, Lebih mengedepankan kepentingan rakyat diatas kepentingan golongna maupun kepentingan pribadi.

\section{Krisis Ekonomi Global Menurut Pandangan Islam}

Menurut pandangan Islam, sebenarnya krisis ekonomi yang terjadi di dunia tidak terlepas dari praktir-praktik ekonomi atau aktivitas ekonomi yang dilakukan bertentangan dengan syariat Islam. Seperti tindakan mengkonsumsi riba (bunga), tindakan korupsi, monopoli, dan tindakan praktik lainnya yang bertentangan dengan syariat Islam. Tidak jarang masyarakat yang menjadikan hal hal tersebut sebagai kebiasaan dan hal yang biasa dalam kehidupan sehari-hari. Mungkin krisis ekonomi adalah salah satu bentuk ancaman dari Allah karena kita sebagai manusia tidak benar-benar memperhatikan semua hal-hal yang diperintahkan dan dilarang olehNya.

Hal ini terdapat dalam firman Allah QS. al-Rum: 41, yang berbunyi: 


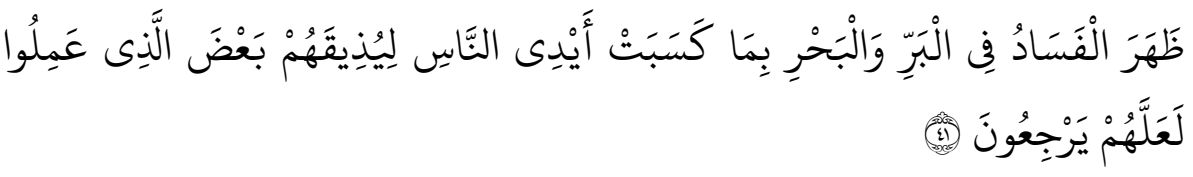

Artinya: "Telah nampak kerusakan di darat dan di laut disebabkan Karena perbuatan tangan manusia, supaya Allab merasakan kepada mereka sebahagian dari (akibat) perbuatan mereka, agar mereka kembali (ke jalan yang benar)." 3

Semua itu terjadi karena ketamakan dan kerakusan manusia yang lebih mementingkan diri sendiri dan ingin menumpuk harta sebanyakbanyaknya dibandingkan dengan memikirkan kemaslahatan umat. Mereka melakukan praktek ekonomi yang bertentangan dengan syariat Islam. Seperti yang telah disebutkan dalam ayat di atas. Merupakan suatu tindakan yang tidak hanya merugikan diri sendiri, namun juga akan merugikan orang lain dan juga merusak lingkungan. Karena mereka tidak menyadari bahwasannya setiap aturan-aturan syariat agama Islam adalah untuk kebaikan umat manusia dan semua yang dilakukan oleh manusia akan dipertanggungjawabkan kelak di akhirat. Jadi sebagai manusia haruslah berhati-hati dalam setiap tindakan yang akan dilakukan. Bukan hanya memikirkan apa yang dilakukan di dunia saja, namun juga harus memikirkan apa yang akan terjadi nanti di akhirat. Islam sebagai satusatunya agama yang sempurna yang diridhoi oleh Allah dari zaman nabi Adam AS sampai nabi Muhammad sebagai penyempurna dimaksudkan untuk memperbaiki kehidupan umat manusia agar selamat didunia dan diakhirat. Sebuah sistem yang juga terdapat akidah, akhlaq dan juga syariat sebagai Undang-Undang bagi kehidupan Manusia.

Di antara keagungan sistem Islam adalah perekonomian dengan sistem Syariah. Di mana sistem Syariah adalah sebuah sistem yang tidak memberlakukan sistem bunga di dalamnya. Dalam sistem Syariah yang digunakan adalah dengan sistem mudârabah, musyârakah, dan sistemsistem lain yang berdasarkan syariat Islam. Jika instrumen dari ekonomi Syariah dapat diimplementasikan dengan baik dan benar maka beberapa masalah krisis ekonomi bisa dihadapi sehingga tidak menimbulkan masalah krisis ekonomi maupun finansial sebagaimana yang saat ini terjadi.

Dalam ekononomi Islam terdapat beberapa instrumen yang menjadikan karakteristik bagi ekonomi Islam yang tidak terdapat dalam sistem ekonomi lainnya. Berikut beberapa karakteristik tersebut:

\footnotetext{
${ }^{3}$ QS. Al-Rum: 41.
} 
a. Time Horizon

Karakteristik ini bernilai pengakuan adanya dua tujuan hidup didunia dan diakhirat. Dalam ekonomi Islam pelaksanaan segala bentuk aktivitas ekonomi harus memiliki nilai ganda, yaitu mencapai keuntungan dunia dan akhirat, serta berimplikasi pada keseriusan berusaha karena akan ada pertanggungjawaban dunia dan akhirat sekaligus. Seorang ekonomi muslim yang baik haruslah memiliki karakteristik time horizon ini agar dapat mencapai tujuan ekonomi. Tujuan ekonomi yang dimaksudkan adalah kesejahteraan dunia dan kesejahteraan akhirat.

Implementasi dari karakteristik ini adalah seorang pelaku ekonomi muslim mempunyai sikap yang sangat hati-hati dan bersungguhsungguh dalam beraktifitas. Jika karakteristik ini dijalankan dengan baik dan benar. Maka akan tercermin sosok manusia yang selalu berlaku adil atas dirinya, orang lain dan Tuhannya sehingga timbul suatu kemaslahatan sosial.

b. Diakuinya Hak Kepemilikan.

Ditinjau dari segi etimologi kepemilikan dalam Islam berarti manusia bolaeh menguasai dan bertindak bebas atas harta yang dimiliki. $^{4}$

Karakteristik ini merupakan pengembangan dari konsep dasar ekonomi Islam tentang harta (kepemilikan). Konsep hak milik dalam Islam berawal dari pendapat bahwa manusia mempunyai kecenderungan dasar (fitrah) memiliki sesuatu harta secara individual tetapi juga membutuhkan pihak lain dalam kehidupan sosialnya. ${ }^{5}$ Sistem Ekonomi Islam mengakui hak seseorang untuk memiliki apa saja yang ia inginkan dari barang-barang produksi ataupun barangbarang konsumsi namun juga mengakui kepemilikan umum. Dalam hal ini ekonomi Islam memadukan antara maslahat individu dan maslahat umum. ${ }^{6}$

Agar tidak terjadi pertentangan penggunaan hak kepemilikan antar pihak, baik individu maupun masyarakat, Islam memberikan kaidahkaidah sebagai berikut:

1. Kemaslahatan masyarakat yang lebih harus didahulukan dari pada kemaslahatan individu.

${ }^{4}$ Jafril Khalil, Jihad Ekonomi Islam, (Depok: Gramata Publising, 2010) 112.

5 Ibid, 108.

${ }^{6}$ Ahmad Izzan, Referensi Ekonomi Syariah, (Bandung: PT Remaja Rosdakarya, 2006) 34. 
2. Meskipun kaidah menghilangkan kesukaran dan mendorong kemaslabatan keduanya merupakan tujuan Syariah namun yang pertama harus didahulukan.

3. Kerugian yang lebih besar tidak boleh ditimpakan untuk menghindari kerugian yang lebih kecil atau kemaslahatan yang lebih besar tidak dapat dikorbankan untuk mendapatkan kemaslahatan yang lebih kecil.

Sedangkan status hak milik yang diberikan kepada manusia mempunyai kedudukan yang telah diatur dalan Islam sebagai:

a) Amanah atau titipan dari Allah karena manusia sebagai khalifah yang diberi tugas untuk mengatur dan memakmurkan alam semesta.

b) Perhiasan dan kenikmatan hidup yang boleh dinikmati dan dimiliki secara baik dan wajar.

c) Sebagai ujian keimanan, terutama dalam hal cara perolehan dan memanfaatkan sumberdaya ekonomi yang diusahakan dan dikuasai.

d) Sebagai bekal (sarana) beribadah kepada Allah. ${ }^{7}$

e) Pada hakikatnya individu adalah wakil masyarakat.

f) Harta benda tidak boleh berada ditangan pribadi (sekelompok) anggota masyarakat. ${ }^{8}$

c. Tidak Ada Transaksi Berbasis Riba

Islam menekankan pentingnya memfungsikan uang pada bidangbidangnya yang normal yaitu sebagai fasilitas transaksi dan alat penilain barang. Diantara faktor penyelewengan uang dari bidangnya yang normal adalah adanya bunga (riba). ${ }^{\text {' }}$

Bunga merupakan fenomena yang mewarnai hampir seluruh transaksi dimuka bumi ini. Dan eksistensi bunga telah dipersamakan dengan riba oleh sebagian besar ulama di dunia. Sehingga keberadaan bunga dilarang oleh Islam.

Sehingga salah satu karakteristik dalam ekonomi islam adalah larangan adanya riba dalam setiap transaksi yang dilakukan dan harus jelas dalam bentuk hukum yang jelas dan tidak muncul secara nyata dan tidak ditolerir sedikitpun. Apabila karakteristik ini masih digunakan oleh para pelaku ekonomi Islam maka ia belum pantas

${ }^{7}$ Ibid, 112.

${ }^{8}$ Suhrawardi K. Lubis, Hukum Ekonomi Islam, (Jakarta: Sinar Grafika, 2000), 6

${ }^{9}$ Ibid, 29. 
dikatakan sebagai pelaku ekonomi Islam. Meskipun secara nyata riba sangatlah sulit untuk dihilangkan dari kehidupan manusia.

Karena bagaimanapun juga riba dalam prakteknya bunga sangat tidak mendukung tercapainya tujuan ekonomi yaitu kesejahteraan. Karena praktek riba merupakan implementasi atas falsafah materialistis dan individualistis yang dikembangkan oleh paham kapitalis.

d. Berfungsinya Institusi Zakat.

Zakat adalah salah satu karekteristik ekonomi Islam mengenai harta yang tidak terdapat dalam perekonomian lain. Sistem perekonomian diluar Islam tidak mengenal tuntutan Allah kepada pemilik harta, agar menyisihkan sebagian harta tertentu sebagai pembersih jiwa dari sifat kikir, dengki, dan dendam.

e. Berjalannya Mekanisme Harga dan Mekanisme Pasar

Hukum asal dari penetapan harga adalah haram, harga merupakan suatu titik temu antara kekuatan nilai permintaan dan nilai penawaran. Sedangkan pasar merupakan pertemuan antara penjual dan pembeli. Islam memandang setiap individu pelaku ekonomi mempunyai kebebasan berusaha dan berkehendak dari kepentingan yang berbeda tetapi sama yaitu memperoleh keuntungan. Sehingga mereka diberi kebebasan mengusahakan keuntungan mereka dengan baik dan wajar.

Permasalahan-permasalahan yang muncul seiring dengan perkembangan sebuah pergeseran terhadap hukum asal. Seperti halnya dalam penetapan harga oleh pemerintah atau penguasa dimungkinkan untuk terwujudnya kemaslahatan sosial. Hal-hal yang terkait dengan mekanisme harga dan pasar, Islam memberikan aturanaturan, diantaranya:

a) pada dasarnya Islam menerima perdagangan bebas, namun perlindungan atas dampak itu harus dilakukan, seperti larangan monopoli, riba, spekulasi dan perjudian serta halnya menghalalkan transaksi yang baik dan halal.

b) Internensi Pemerintah dalam hubungannya dengan mekanisme pasar adalah dalam batas kontrol dan regulasi dalam rangka pertumbuhan ekonomi, stabilitas ekonomi dan harga serta pendistribusian yang merata.

f. Diakuinya Motif Mencari Keuntungan Dalam Konteks Keseimbangan (Equilibrium).

Yang dimaksud dengan konsep equilibrium adalah kesinambungan antara dua sisi yang berpasangan, yaitu meliputi keseimbangan dalam hal lahir dan batin, dunia dan akhirat, pribadi dan sosial, hak dan 
kewajiban. Pengaruh dalam perilaku manuia yang muncul dari nilai keseimbangan ini adalah sifat moderasi (kesederhanaan), berhemat, menjauhi pemborosan dalam tindakan ekonomi. ${ }^{10}$

Beberapa firman Allah yang berisi tentang keseimbangan yaitu:

1) QS. Al-Baqarah: 143.

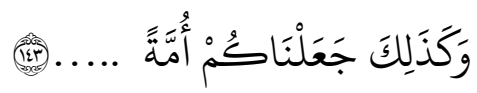

Artinya: "Begitukan kami jadikan kamu sebagai umat yang

2) Qs Al-Jumuah: 10.

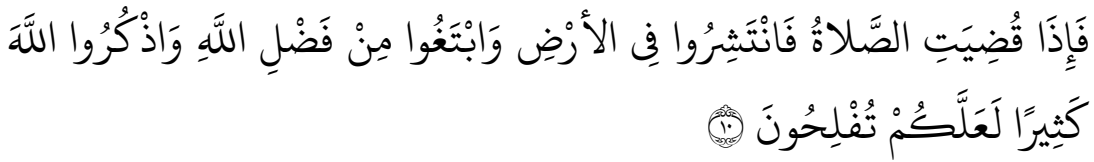

Artinya: "Apabila Telah ditunaikan shalat, Maka bertebaranlah kamu di muka bumi; dan carilah karunia Allah dan ingatlah Allah banyak-banyak supaya kamu beruntung." 12

g. Ekonomi Islam Terikat Dengan Akidah, Syariah (Hukum) Dan Moral.

Hubungan ekonomi Islam dengan akidah tampak jelas dalam banyak hal, seperti pandangan Islam terhadap alam semesta yang disediakan untuk kepentingan manusia. Hubungan ekonomi Islam dengan Syariah tersebut memungkinkan aktivitas ekonomi dalamIslam menjadi ibadah.

Sedangkan hubungan ekonomi Islam dengan moral terdapat beberapa hal dalam Islam yaitu:

a) Larangan terhadap pemilik dalam penggunaan hartanya yang dapat menimbulkan kerugian atas harta orang lain atau kepentingan masyarakat.

b) Larangan melakukan penipuan terhadap transaksi.

Dengan melihat beberapa karakteristik ekonomi Islam yang tidak terdapat dalam sistem ekonomi lainnya tersebut sudah membuktikan bahwa Islam telah didesain sedemikian rupa untuk kehidupan manusia. Bahkan untuk hal yang kecil sekalipun Islam telah mengaturnya. Dan untuk kemsalahatan umat didunia maupun diakhirat. Namun manusia lebih mementingkan nafsunya dan lebih memilih hal-hal yang dianggap lebih menguntungkan baginya. Padahal

10 Ibid, 115.

11 QS. Al-Baqarah: 143.

${ }^{12}$ QS. Al-Jumu'ah: 10. 
ia tidak menyadari bahwa hal-hal yang dianggapnya menguntungkan tersebut telah melanggar syariat Islam. Dan justru akan merugikannya kelak dikemudian hari.

Dalam Islam ada beberapa cara untuk meminimalisir dampak dari krisis ekonomi, yaitu:

a) Zakat

Secara etimologi, zakat memiliki beberapa makna yang di antaranya adalah suci. Yang terdapat dalam firman Allah SWT dalam al-Qur'an QS. Al-Syams: 9:

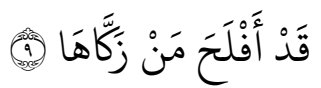

Artinya: "Sesunggubnya beruntunglah orang yang mensucikan jïwa itu." 13

Maksudnya adalah suci dari doa dan kemaksiatan. Selain itu, zakat bisa bermakna tumbuh dan nerkah. Secara Syar'i zakat adalah swdekah tententu yang diwajibkan dalam syariah terhadap harta orang kaya dan diberikan kepada orang yang berhak menerimanya. Zakat merupakan salah satu pilar rukun Islam yang merupakan suatu strategi dari sistem perekonomian Islam yang dapat memberikan kontribusi besar terhadap penanganan problematika sosial lainnya. Karena zakat dalam pandangan Islam bertujuan untuk memberikan hak fakir miskin yang tersimpan didalam kekayaan orang-orang kaya. ${ }^{14}$

Menurut DR. Yusuf Qardhawi, zakat merupakan suatu sistem yang belum pernah ada pada agama selain agama Islam juga pada peraturan-peraturan pada manusia. Zakat mencakup sistem keuangan, ekonomi, sosial, politik, moral dan agama sekaligus. Berikut penjelasannya:

1) Zakat adalah sistem keuangan dan ekonomi

2) Karena zakat merupakan pajak harta yang telah ditentukan jumlahnya dan kapan waktu pelaksanaannya.

3) Zakat sebagai sistem sosial

Zakat sebagai sistem sosial yang berusaha menolong masyarakat miskin dengan cara menyalurkan dana dari orang-orang kaya kepada orang-orang miskin atau kurang mampu.

Sebagai sistem politik; Zakat dikatakan sebagai sistem politik karena pada asalnya negaralah yang mengelola pemungutan dan pembagiannya.

${ }^{13}$ QS. Al-Syams: 9.

14 Said Sa'ad Marthon, Ekonomi Islam di Tengah Krisis Ekonomi Global, (Jakarta: Zikrul Hakim, 2007), 118. 
Sebagai sistem moral; Zakat sebagai sistem moral karena zakat bertujuan untuk memebersihkan hati dari sifat kikir karena memiliki harta yang berkecukupan sekaligus jiwa hasud dan dengki terhadap orang-orang yang kekurangan. Juga dapat menumbuhkan rasa kasih sayang terhadap sesama, karena dalam Islam sesama umat muslim adalah saudara.

Sebagai sistem keagamaan; Zakat sebagai sistem keuangan karena dengan menunaikan zakat adalah suatu ibadah dan suatu kewajiban sebagai umat muslim apabila memiliki harta yang lebih dari nisabnya. Dan sebagai sarana untuk mendekatkan diri kepada Allah SWT.

b) Mengembangkan Perbankan dengan sistem Syariah.

Akhir-akhir ini ekonomi syariah semakin populer. Banyak lembaga-lembaga yang mulai menerapkan sistem Syariah termasuk juga dalam perbankan. Banyak bank-bank yang awalnya hanya menggunakan sistem konvensional kini mulai membuka sistem dengan sistem Syariah.

Hal ini tak hanya terjadi di negara-negara Islam saja, tetapi juga di negara barat. Hal ini ditandai dengan makin banyaknya bank yang menerapkan konsep Syariah didalamnya. Melihat kemungkinan tersebut, tidak tertutup kemungkinan bahwa suatu saat nanti seluruh aspek perekonomian akan berbasis syariah. Hal ini menunjukkan bahwasannya nilai-nilai Islam dapat diterima di berbagai karena sifatny yang universal dan tidak ekslusif. Nilai-nilai itu misalnya keadilan dan perlakuan yang sama dalam meraih kesempatan berusaha. Di Indonesia sendiri, konsep ekonomi syariah telah diterapkan mulai tahun 1991. Yakni sejak bank muamalat Indonesia (BMI) berdiri.

Kondisi perbankan Syariah pada tahun mendatang diperkiraan akan terus membak. Hal ini dibuktikan dengan minat masyarakat pada perbankan syariah masih tinggi. Dalam rangka peningkatan jangkauan, ada kemudahan untuk membuka kantor pelayanan. Hal itu diharapkan dapat berpengaruh pada minat masyarakat. Di sisi lain, secara Internasional, peluang memanfaatkan investasi asing, khususnya dari Timur Tengah ke dalam sistem perekonomian Indonesia, masih terbuka lebar.

Industri keuangan berbasis Syariah secara internasional tumbuh sangat pesat, sehingga memberikan peluang besar bagi sistem keuangan Syariah. Harapan untuk dapat menerbitkan obligasi berbasis Syariah menjadi semakin besar dengan adanya minat pemerintah untu menerbitkan global obligasi berbasis Syariah. Hal ini berpotensi meningkatkan variasi instrumen keuangan syariah yang akan sangat 
berguna bagi likuiditas sistem keuangan Syariah. Sejalan dengan perkemabangan ekonomi global dan meningkatkan minat masyarakat, perbankan Syariah menghadapi tantangan besar.

Dalam hal ini pemerintah tatap berusaha mengembankan perbankan Syariah. Pemerintah mengharapkan sistem perbankan Syariah sebagai bagian dari sistem ekonomi nasional yang dapat merespons agenda nasional. Mengingat pentingnya pembangunan ekonomi Syariah, maka pemerintah pun memberikan dukungan sepenuhnya bagai pengembangan sistem ekonomi Syariah dengan melakukan perubahan Undang-Undang (UU) No. 7/1992 tentang perbankan menjadi UU No. 10/1998. Undang-Undang ini mengatur pranata hukum bagi keberadaan bank Syariah di Indonesia.

Berdasarkan Undang-Undang ini pula, bank umum konvensional dipebolehkan membuka usaha dengan prinsip Syariah melalui pembukaan Unit Usaha Syariah. Pada tahun 1999 pemerintah mengeluarkan UU No.23/1999 yang kemudian diamandemenkan dengan UU No. 3/2004 tentang bank Indonesia. Undang-Undang ini memberikan wewenang kepada Bank Indonesia (BI) untuk menjalankan tugasnya berdasarkan prinsip Syariah.

Penetapan UU Perbankan Syariah selanjutnya diharapkan dapat menjadi faktor pemacu pertumbuhan perbankan Syariah, baik dalam membuka jaringan bank umum Syariah maupun Bank Pembiayaan Rakyat Syariah. Secara faktual, keunggulan perbankan Syariah telah terbukti dalam masa krisis. Pada waktu bank konvensional mengalami guncangan akibat badai krisis pada pertengahan 1997, perbankan Syariah dengan sistem bagi hasil terbukti selamat dari badai krisis tersebut.keberadaaan UU Syariah diharapkan akan semakin meumbuhkan perekonomian nasional, serta diharapkan pula dapat membawa dampak pada aliran dana investasi ke Indonesia yang semakin meningkat, terutama dari negara-negara Timur Tengah.

Beberapa Keistimewaan Perbankan Syariah jika dibandingkan dengan Perbankan Konvensional:

1) Pertumbuhan ekonomi.

Tujuan utama perbankan Syariah adalah pertumbuhan ekonomi dalam kehidupan masyarakat. Untuk merealisasikan hal tersebut, kegiatan perankan terfokus pada kegiatan produksi bik dalam perindustrian, pertanian, maupun perdagangan.

2) Jaminan Sosial Dan Pemerataan Kekayaan.

Dengan adanya pengelolaan zakat, diharapkan dana yang telah terkumpul dapat didistribusikan kembali kepada pihak-pihak yang 
berhak menerima. Dengan demikian, kebutuhan fakir-miskin bisa tetap dan meminimalisir tindak kejahatan.

3) Prinsip Operasional.

Perbankan syariah menggunakan nilai-nilai syariah sehingga memungkinkan untuk menciptakan kemaslahatan bagi kehidupan masyarakat.

4) Dalam perbankan Syariah terdapat dewan pengawas atas keabsahan transaksi atau operasional yang ada. Dewan pengawas dalam perbankan Syariah bertujuan untuk mengawasi apakah lembaga tersebut benar-benar menerapkan sistim Syariah dan tidak menyeleweng dari syariat

5) Memberikan peluang bagi masyarakat untuk melakukan bisnis.

Biasanya perbankan Syariah bisa untuk memberikan pembiayaan bagi mereka yang mau melakukan bisnis dengan akad yang telah disepakati. Dan perbankan Syariah akan terus mengawasi bisnis yang dilakukan oleh orang yang telah menajukan pembiayaan tersebut. Yang nantinya akan digunakan sebagai penilaian apakah bisnis tersebut layak untuk terus mendapatkan pembiayaan atau tidak.

Namun disisi lain, selain keistimewaan yang dimiliki oleh Perbankan Syariah, terdapat beberapa faktor dan kondisi yang dapat menghambat pertumbuha perbankan Syariah, yaitu:

1) Tidak ada atau kurangnya pemahaman yang komprehensif dari masyarakat tentang mekanisme dan operasional perbankan Syariah.

2) Di beberapa negara belum ada Undang-Undanga khusus yang mengatur tentang operasional perbankan Syariah secara utuh, Perbankan Syariah masih menggunakan Undang-Undang perbankan konvensional di beberapa negara.

3) Adanya hegemoni perbankan konvensional dalam pasar. Market share perbankan syariah masih relatif kecil.

4) Produk yang ditawarkan oleh perbankan syariah masih memerlukan penyesuaian terhadap kondisi yang ada.

5) Minimnya sumber daya manusia sebagai tenaga pengelola perbankan syariah.

6) Masyarakat belum bisa menerima sepenuhnya akad-akad yang terdapat dalam pebankan Syariah, seperti murabahah, mudharabah dan lainnya yang msih mengalami perdebatan. Masyarakat lebih memandang bahwa perbankan konvensional dengan sistem bunganya lebih menguntungkan daripada perbankan Syariah. 
7) Terkadang masih terdapat tindakan yang tidak konsisten dalam erbankan Syariah.karena terkadang masih terdapat perbankan yang menggunakan nama Syariah namun dalam prakteknya masih terdapat adanya sistem bunga.

6) Sistem Mata uang Dirhan dan Dinar.

Instrumen yang sangat strategis dalan perekonomian Islam adalah sistem mata uang dinar dan dirham. Hal ini mengingat bahwa sistem moneter dalam Islam adalah berbasis emas dan perak. Diterapkannya sistem perdagangan dengan menggunakan emas dan perak dalam mata uang dinar (gold dinar) dan dirham dalam kekhalifahan Islam telah membuktikan terkendalinya angka inflasi.

Inflasi sesungguhnya merupakan suatu kemudlaratan ekonomi yanng sejatinya harus ditekan, karena dengan terjadinya inflasi berarti telah terjadi sebuah hal yang signifikan terhadap peningkatan kemiskinan masyarakat. Dengan demikian, maka penerapan sistem mata uang dinar dan dirham secara luas, akan ikut mengurangi tingkat inflasi yang selama ini terus membayangi sistem perekonomian berbagai negara akibat penerapan sistem ekonomi konvensional yang menggunakan uang kertas yang tak terkendali. Sehingga berkurangnya angka inflasi sebagai dampak positif dari diterapkannya gold dinar. Sesungguhnya merupakan salah satu upaya untuk mengurasi kemiskinan masyarakat.

Jika diperhatikan dengan seksama, ternyata dengan diterapkan mata uang dinar dan dirham akan mendapatkan beberapa keuntungan, baik secara mikro maupun makro. Keuntungan tersebut diantaranya yaitu:

1) gold dinar memiliki stabilitas tinggi yang nilainya tidak fluktuatif sehingga jika dikomparasi dengan mata uang lainnya tidak akan terdepresiasi bahkan akan terus terapresiasi. Sejarah telah membuktikan akan hal ini, bahwa pada zaman Nabi Muhammad SAW, harga seekor ayam harganya satu dirham, dimana dengan uang yang sama seekor ayam masih bisa dibeli. satu dirham saat ini setara dengan tiga gram perak. Hal ini membuktikan bahwa emas (dinar) dan perak (dirham) merupakan anti inflasi. Sehingga pada masa Nabi Muhammad SAW yang dilanjutkan pada masa Khulafaur Rasyidin dan para sesudahnya dalam pengelolaan pemerintahannya sangat jarang terjadi resesi ekonomi. 
2) Gold dinar merupakan mata uang yang berbasis komoditi, karena adanya keseimbangan antara nilai instrinsik dengan nilai nominal yang terdapat pada gold dinar. Bahkan nilai instrinsik dari gold dinar merupakan garansi dan perlindungan jika terjadi situasi yang tidak diinginkan.

3) Penerapan dinar dan dirham akan terhindarkan dari upaya menjadikan uang sebagai komoditas.

Karena krisis ekonomi global saat ini diantaranya terjadi karena tidak difungsikannya secara penuh sebagaimana mestinya yang dimana uang sebagai alat tukar, akan tetapi fungsi uanng telah bergeser menjadi komoditas yang diperjualbelikan sehingga sangat menguntungkan bagi para pelaku ekonomi pada berbagai transaksi maya di pasar uang.

Kondisi tersebut akan sangat menguntungkan bagi pihak yang memiliki dana banyak untuk mengendalikan pasar uang. Sehingga terjadilah ketergantungan pada sutu negara yang labil dalam hal politik maupun ekonomi dan akan mudah dikuasai oleh negara-negara yang memiliki power.

4) Tidak seperti halnya mata uang kertas yang sangat mudah untuk dipalsukan, maka penggunaan gold dinar dapat menghilangkan upaya pemalsuan uang dari pihak-pihak tertentu

Tidak terjadinya jurang pemisah sangat lebar antara si kaya dan si miskin. Dengan terdistribusinya pendapatan melalui pengelolaan zakat yang tepat sasaran serta diberlakukannya mata uang dinar dan dirham akan menjadikan sebuah keseimbangan antara sektor finansial dengan sektor riil, karena jumlah uang yang beredar sama banyaknya dengan nilai barang dan jasa dalam perekonomian, sehingga perkembangan sektor keuangan tidak akan berjalan sendiri, tanpa terkait dengan sektor riil. Hal ini akan berimplikasi terhadap pertumbuhan ekonomi sekaligus terciptanya stabilitas ekonomi masyarakat. Dalam ekonomi Islam, sektor finansial selalu mengikuti pertumbuhan sektor riil. Inilah yang menjadi perbedaan konsep ekonomi Islam dengan ekonomi konvensional yang kapitalistik, dimana dalam ekonomi kapital, pemisahan antara sektor finansial sengan sektor riil merupakan keniscayaan. Implikasi dari adanya pemisahan itu, maka ekonomi dunia sangat rawan terhadap gonjangganjing krisis. Hal ini disebabkan pelaku ekonomi menggunakan uang tidak untuk kepentingan sektor riil, tetapi untuk kepentingan spekulasi mata uang semata. Akibat dari adanya spekulasi tersebut, maka jumlah uang yang beredar sangat tidak seimbang degan jumlah barang pada sektor riil. 
Dengan terciptanya sistem ekonomi Syariah, maka kita sebagai manusia akan terhindar dari perbuatan-perbuatan yang menyimpang dari syariat agama Islam seperti gharar, riba, dan maisir. Sehingga selain sebagai mencari keuntungan juga akan bernilai sebagai ibadah dan akan mendapatkan keberkahan dari Allah SWT. Karena apapun yang kita lakukan akan dimintai pertanggungjawaban kelak diakhirat.

\section{Kesimpulan}

Krisis ekonomi global terjadi karena permasalahan ekonomi pasar di seluruh dunia yang tidak dapat dielakkan karena kebangkrutan maupun adanya situasi ekonomi yang berantakan. Sektor yang terkena imbasan krisis ekonomi global adalah seluruh sektor bidang kehidupan. Krisis ekonomi global berawal dari Amerika Serikat (AS), kemudian menjalar ke hampir seluruh negara-negara dunia. Bukan hanya negara-negara maju yang terkena imbas krisis, namun juga negara-negara berkembang. Krisis ekonomi secara nyata mengarah ke resesi.

Menurut pandangan Islam, sebenarnya krisis ekonomi yang terjadi didunia tidak terlepas dari prakter-praktek ekonomi atau aktivitas ekonomi yang dilakukan bertentangan dengan syariat Islam. Seperti tindakan mengkonsumsi riba (bunga), tindakan korupsi, monopoli, dan tindakan praktek lainnya yang bertentangan dengan syariat Islam. Tak jarang masyarakat yang menjadikan hal hal tersebut sebagai kebiasaan dan hal yang biasa dalam kehidupan sehari-hari. Mungkin krisis ekonomi adalah salah satu bentuk ancaman dari Allah karena kita sebagai manusia tidak benar-benar memperhatikan semua hal-hal yang diperintahkan dan dilarang oleh-Nya.

Dalam Islam ada beberapa cara untuk meminimalisir dampak dari krisis ekonomi, yaitu: Zakat, Mengembangkan Perbankan dengan sistem Syariah, dan Sistem Mata uang Dirhâm dan Dinâr. 


\section{Daftar Pustaka}

Al-Qur'an.

Izzan, Ahmad. Referensi Ekonomi Syariah. Bandung: PT Remaja Rosdakarya, 2006.

Khalil, Jafril. Jihad Ekonomi Islam. Depok: Gramata Publising, 2010.

Marthon, Said Sa'ad. Ekonomi Islam di Tengah Krisis Ekonomi Global. Jakarta: Zikrul Hakim, 2007.

Syadullah, Makmun. Krisis Ekonomi Global \& Dampak Fiskal. Yogyakarta:Tiara Wacana, 2010 